\title{
PENERAPAN PSAK NO. 18 TENTANG AKUNTANSI DAN PELAPORAN PROGRAM MANFAAT PURNAKARYA PADA UNIVERSITAS SURABAYA
}

\author{
Agung Sri Wardhani* \\ agung.wardhani@yahoo.co.id, wardhani@staff.ubaya.ac.id \\ Bambang Herwanto* \\ herwanto@staff.ubaya.ac.id
}

\begin{abstract}
Pension scheme is the employees' income management program that can be set aside during the employment period and it is invested so when the employees are retired, they receive the pension money regularly during their lifetime. The managers of pension fund in presenting the financial statements must refer to the prevailing rules. Guidelines of organizing financial statements for pension fund has been set in Undang Undang No. 11. Tahun 1992. Besides that, it has to be consistent with PSAK (Pernyataan Standar Akuntansi Keuangan - Standard Statement of Financial Accountancy) No. 18. The purpose of this research is to find out and analyze the application of PSAK no. 18 on the management of pension fund in Universitas Surabaya (UBAYA). The research method used is qualitative descriptive. The result of the research showed that overall UBAYA's management of pension fund is already matched with PSAK no. 18.
\end{abstract}

Keywords: pension fund, Standard Statements of Financial Accountancy no. 18.

\section{Pendahuluan}

Program dana pensiun merupakan program pengelolaan pendapatan karyawan yang disisihkan selama masa kerja karyawan tersebut, yang kemudian diinvestasikan, sehingga pada saat karyawan tersebut pensiun, karyawan tersebut masih dapat menerima pembayaran secara berkala selama masa hidupnya. Dengan dikeluarkannya Undang Undang No.11 Tahun 1992 tentang Dana Pensiun banyak perusahaan di Indonesia yang menyelenggarakan program dana pensiun bagi karyawannya. Program dana pensiun tersebut dapat dikelola sendiri

* Dosen Program Studi Akuntansi Politeknik Ubaya, Surabaya 
oleh perusahaan ataupun melalui lembaga yang lain baik lembaga pemerintah maupun lembaga swasta. Berdasarkan Undang Undang No. 11 Tahun 1992, dana pensiun mengatur mengenai hak peserta dana pensiun, menyediakan standar peraturan yang menjamin diterimanya manfaat pensiun pada masa pensiun, pengelolaan, serta pengurusan dana pensiun dan pedoman bagi pengelola dana pensiun.

Tujuan pengelolaan dana pensiun adalah memberikan manfaat, kesejahteraan, dan jaminan kepada para karyawannya. Dengan adanya program dana pensiun ini diharapkan dapat meningkatkan motivasi dan ketenagakerjaan sehingga dapat meningkatkan produktivitas para karyawannya, yang pada akhirnya dapat memberikan keuntungan bagi perusahaan. Program dana pensiun ini merupakan tabungan bagi karyawan pada masa yang akan datang. Oleh karena itu, setiap instansi sebaiknya menyelenggarankan program dana pensiun bagi karyawanannya. Pengelolaan dana pensiun dapat diselenggarakan oleh instansi tersebut atau diserahkan kepada pihak lain. Selain itu, dalam Undang Undang Republik Indonesia Nomor 3 Tahun 1992 tentang Jaminan Sosial Tenaga Kerja (Jamsostek) juga telah diatur mengenai jaminan hari tua karyawan. Dalam pasal 14 menjelaskan bahwa jaminan hari tua tersebut dapat diberikan secara sekaligus atau berkala atau sebagian dan berkala kepada tenaga kerja yang telah mencapai usia 55 tahun atau cacat total tetap setelah ditetapkan oleh dokter. Jelas dinyatakan bahwa sebaiknya suatu instansi atau lembaga perlu untuk menyelenggarakan program dana pensiun.

Selain Undang Undang No.11 Tahun 1992, pengelola dana pensiun juga harus mematuhi Pernyataan Standar Akuntansi Keuangan (PSAK). PSAK merupakan pedoman bagi lembaga atau intitusi dalam menyusun Laporan Keuangan. Dana pensiun dalam menyajikan laporan keuangan harus memiliki dasar dan arahan, agar laporan keuangan yang disajikan memberikan informasi yang benar dan berlaku umum. Informasi tersebut dapat digunakan oleh berbagai pihak. Pengelola dana pensiun memikul tanggung jawab utama dalam penyusunan dan penyajian laporan keuangan. Pengelola dana pensiun juga berkepentingan dengan informasi yang disajikan dalam laporan keuangan, informasi manajemen dan keuangan tersebut berguna bagi pengelola dana pensiun dalam melaksanakan tanggung jawab perencanaan, pengendalian, dan pengambilan keputusan. Pada dasarnya pengelola dana pensiun memiliki kemampuan untuk menentukan bentuk dan isi informasi laporan untuk memenuhi kebutuhannya sendiri. Namun demikian, pelaporan informasi tetap harus berada dalam kerangka dasar penyajian yang benar dan belaku secara umum. PSAK No. 18 mengatur bagaimana akuntansi dan penyusunan laporan keuangan terkait dengan dana pensiun. Dalam PSAK No. 18 tersebut pelaporan program manfaat purnakarya ditujukan untuk semua peserta sebagai suatu kelompok, di mana pernyataan ini tidak mengatur peloporan peserta secara individual tentang hal manfaat purnakaryanya.

Pengelolaan dana pensiun di Universitas Surabaya, menurut Undang Undang No. 11 Tahun 1992, termasuk jenis dana pensiun pemberi kerja. Sedangkan menurut PSAK no. 18 pengelolaan dana pensiun di Universitas Surabaya termasuk dalam program manfaat pasti, di mana ketentuan pendanaan didasarkan pada penghasilan karyawan dan atau masa kerja karyawan. Melihat pentingnya pengelolaan dana pensiun tersebut, maka pengelolaan keuangan dana pensiun di Universitas Surabaya juga perlu ditinjau pelaksananya apakah telah sesuai dengan PSAK No. 18, yaitu Akuntansi dan Pelaporan Progam Manfaat Purnakarya. 


\section{Pengertian Dana Pensiun}

MenurutUndang Undang Nomor 11 Tahun 1992, Dana Pensiun adalah badan hukum yang mengelola dan menjalankan program menjanjikan manfafat pensiun. Sedangkan menurut PSAK 18 tentang Akuntansi Dana Pensiun menjelaskan bahwa program manfaat purnakarya adalah perjanjian untuk setiap entitas yang menyediakan manfaat purnakarya untuk karyawan pada saat atau setelah berhenti bekerja (baik dalam bentuk iuran bulanan atau lumpsum) ketika manfaat semacam itu atau iuran selanjutnya untuk karyawan, dapat ditentukan atau diestimasi sebelum purnakarya berdasarkan ketentuan yang terdapat dalam dokumen atau praktik entitas.

\section{Jenis dan Status Hukum Dana Pensiun}

Perkembangan dana pensiun di Indonesia dapat dikelola oleh sektor publik maupun sektor swasta. Dalam penelitian yang dilakukan Saefuloh, dkk (2015), menjelaskan bahwa terdapat empat badan yang mengelola dana pensiun yaitu:

1. Tabungan dan Asuransi Pensiun (Taspen) yaitu program pensiun yang khusus diberikan kepada pegawai negeri sipil (PNS).

2. Asuransi Angkatan Bersenjata Republik Indonesia (Asabri), yaitu program pensiun yang diberikan khusus untuk angora TNI.

3. Jaminan Sosial Tenaga Kerja (Jamsostek) melalui UU No. 3 Tahun 1992 tentang Jamsostek bagi perusahaan yang ikut Jamsostek, yaitu program jaminan hari tua (JHT) yang digunakan untuk karyawaan, baik swasta maupun BUMN.

4. Dana Pensiun Pemberi Kerja (DPPK) atau Dana Pensiun Lembaga Keuangan (DPLK), yaitu program pensiun untuk karyawan dan pekerja mandiri.

Berikut ini tabel penyelenggara Program Pensiun di Indonesia (lihat Tabel 1).
Jenis dana pensiun berdasarkan Undang Undang Nomor 11 Tahun 1992 dibagi menjadi dua, yaitu:

1. Dana Pensiun Pemberi Kerja

Dana pensiun yang dibentuk untuk menyelenggarakan progam pensiun bagi karyawan. Pembentukan dana pensiun pemberi kerja didasarkan pada pernyataan tertulis pendiri yang menyatakan keputusan untuk mendirikan dana pensiun dan memberlakukan peraturan dana pensiun. Di mana peraturan dana pensiun ditetapkan oleh pendiri dana pensiun.

2. Dana Pensiun Lembaga Keuangan

Dana pensiun yang hanya menyelengarakan program Pensiun Iuran Pasti. Bank dan perusahaan asuransi jiwa dapat bertindak sebagai pendiri dana pensiun lembaga keuangan dengan memenuhi ketentuan yang ditetapkan oleh Peraturan Pemerintah. Di mana untuk mendirikan dana pensiun lembaga keuangan, bank atau perusahaan asuransi jiwa wajib mengajukan permohonan pengesahan kepada Menteri dengan melampirkan peraturan dana pensiun.

Sedangkan menurut PSAK 18 menjelaskan program dana pensiun dibagi menjadi dua yaitu:

1. Program Iuran Pasti

Program Iuran Pasti adalah program manfaat purnakarya di mana jumlah yang dibayarkan sebagai manfaat purnakarya ditetapkan berdasarkan iuran ke suatu dana bersama pendapatan investasi selanjutnya. Dalam progam ini termasuk program iuran pasti yang diatur dalam peraturan dan perundang-undangan yang berlaku.

2. Program Manfaat Pasti

Program Manfaat Pasti adalah program manfaat purnakarya di mana jumlah yang dibayarkan sebagai manfaat purnakarya ditentukan dengan mengacu pada 
formula yang biasanya didasarkan pada penghasilan karyawan dan atau masa kerja karyawan. Dalam program ini termasuk program manfaat pasti yang diatur dalam peraturan dan perundangundangan yang berlaku.

\section{Manfaat Dana Pensiun}

Menurut Taswan (2015 : 5), ada lima manfaat pensiun yaitu:

1. Manfaat Pensiun Normal;

2. Manfaat Pensiun Dipercepat;

3. Manfaat Pensiun Cacat;

4. Manfaat Pensiun Ditunda;

5. Manfaat Pensiun Janda/Duda/Anak.

Menurut Wahab (2005: 5), manfaat pensiun sebagai berikut:

1. Manfaat Pensiun Normal adalah manfaat pensiun bagi peserta yang mulai dibayarkan pada saat peserta pensiun telah mencapai usia normal atau sesudahnya. Usia Pensiun Normal dite- tapkan 56 tahun, Usia Wajib Pensiun ditetapkan 60 tahun.

2. Manfaat Pensiun Dipercepat adalah manfaat pensiun bagi peserta yang berhenti bekerja pada usia sekurang-kurangnya 46 tahun.

3. Manfaat Pensiun Cacat adalah manfaat pensiun bagi peserta yang berhenti bekerja karena dinyatakan cacat oleh dokter yang ditunjuk oleh pemberi kerja.

4. Manfaat Pensiun Ditunda adalah hak atas pensiun ditunda yang dibayarkan pada saat usia pensiun dipercepat atau setelahnya. Hak atas pensiun ditunda diberikan kepada peserta yang berhenti bekerja sebelum mencapai usia pensiun dipercepat dan mempunyai masa kerja sekurang-kurangnya tiga tahun.

\section{Akuntansi Dana Pensiun menurut PSAK No. 18}

Laporan keuangan dana pensiun sesuai dengan PSAK 18 sebagai berikut:

1. Laporan keuangan program iuran pasti

Tabel 1. Penyelenggara Program Pensiun di Indonesia

\begin{tabular}{|c|c|c|c|c|}
\hline Progam & \multicolumn{4}{|c|}{ Progam Pensiun } \\
\hline Sektor & \multicolumn{2}{|c|}{ Publik } & \multicolumn{2}{|c|}{ Swasta } \\
\hline Badan & Taspen & Asabri & $\begin{array}{lr}\text { UU No.3 } & \text { Tahun } \\
1992 & \text { dan UU } \\
\text { No.13 } & \text { Tahun } \\
2003 & \\
\end{array}$ & Dana Pensiun \\
\hline Kepesertaan & PNS & $\begin{array}{l}\text { TNI, POLRI dan PNS TNI- } \\
\text { POLRI }\end{array}$ & \multicolumn{2}{|c|}{ BUMN dan Non BUMN } \\
\hline Partisipasi & WAJIB & Wajib & Wajib & Sukarela \\
\hline Lembaga & TASPEN & Asabri & Jamsostek & DPPK/DPLK \\
\hline Peraturan & $\begin{array}{l}\text { UU No.11 tahun } 1969 \text {, } \\
\text { UU No.8 Tahun } 1974 \\
\text { yang diubah dengan UU } \\
\text { No.43 Tahun 1999 ( UU } \\
\text { no. } 5 \text { Tahun 2014) dan PP } \\
\text { no.25 Tahun 1981 }\end{array}$ & $\begin{array}{l}\text { UU No.6 Tahun 1966, UU } \\
\text { No.8 tahun } 1974 \text { yeng diubah } \\
\text { dengan UU NO. } 43 \text { Tahun } 1999 \\
\text { ( UU No.2 Tahun } 2002 \text { dan UU } \\
\text { No. } 2 \text { Tahun 2002), PP No.67 } \\
\text { Tahun } 1991 \text { dan PP No.68 } \\
\text { Tahun } 1991\end{array}$ & $\begin{array}{l}\text { UU No. } 3 \text { Tahun } \\
1992\end{array}$ & $\begin{array}{l}\text { UU No.11 } \\
\text { tahun } 1992\end{array}$ \\
\hline $\begin{array}{l}\text { Jenis } \\
\text { Program }\end{array}$ & PPMP & PPMP & PPIP & PPMP/PPIP \\
\hline
\end{tabular}

Sumber: Dari berbagai sumber jurnal dan buku. 
berisikan laporan asset neto tersedia untuk manfaat purnakarya dan penjelasan mengenai kebijakan pendanaan.

Tujuan pelaporan program iuran pasti adalah memberikan informasi secara periodik mengenai penyelenggaran program purnakarya dan kinerja investasinya. Tujuan tersebut dipenuhi dengan menyusun laporan, antara lain terdiri atas:

a. Penjelasan atas kegiatan signifikan program manfaat purnakarya selama suatu periode pelaporan dan dampak setiap perubahan terkait dengan program tersebut, keanggotaan, syarat, dan kondisi.

b. Pelaporan tentang transaksi dan kinerja investasi selama periode pelaporan dan posisi keuangan program purnakarya pada akhir periode pelaporan.

c. Penjelasan atas kebijakan investasi.

2. Laporan keuangan program manfaat pasti terdiri atas:

a. Laporan yang menyajikan:

- Asset neto tersedia untuk manfaat purnakarya.

- Nilai kini aktuaris atas manfaat purnakarya terjanji yang membedakan antara manfaat telah menjadi hak (vested benefits) dan manfaat belum menjadi hak (non-vested benefits).

b. Laporan asset neto tersedia untuk manfaat purnakarya termasuk adalah satu dari:

- Catatan yang mengungkapkan nilai kini aktuaria atas manfaat purnakarya terjanji, yang membedakan antara manfaat telah menjadi hak dan manfaat belum menjadi hak; atau

- Referensi atas informasi asset neto tersedia untuk manfaat purnakarya disertakan dalam laporan aktuaris.

\section{Pengungkapan}

Laporan keuangan progam manfaat purnakarya yeng berupa manfaat pasti atau iuran pasti, berisi informasi mengenai:

1. Laporan perubahan asset neto tersedia untuk manfaat purnakarya;

2. Ringkasan dari kebijakan akuntansi yang signifikan; dan

3. Penjelasan mengenai progam purnakarya dan pengaruh setiap perubahan progam purnakarya selama peiode tersebut.

Laporan keuangan yang disediakan oleh progam manfaat purnakarya meliputi:

1. Laporan asset neto tersedia untuk manfaat purnakarya mengungkapkan:

- Asset pada akhir periode bersangkutan sesuai klasifikasinya

- Dasar nilai asset

- Rincian setiap investasi tunggal melebihi $5 \%$ dari asset neto tersedia untuk manfaat purnakarya atau 5\% untuk setiap kelas atau jenis surat berharga

- Rincian setiap investasi pemberi kerja

- Liabilitas kecuali nilai kini aktuaria atas manfaat purnakarya terjanji.

2. Laporan perubahan asset neto tersedia untuk manfaat purnakarya menyajikan hal-hal sebagai berikut:

- Iuran pemberi kerja;

- Iuran karyawan;

- Pendapatan investasi seperti bunga dan deviden;

- Pendapatan lain-lain;

- Manfaat yang dibayarkan dan terutang;

- Beban administrasi;

- Beban lain-lain;

- Pajak pengahasilan;

- Laba rugi pelepasan investasi dan perubahan nilai investasi;

- Transfer dari dan untuk program purnakarya lain; 
3. Penjelasan mengenai kebijakan pendanaan.

\section{Penelitian Sebelumnya}

Thomas (2017) dengan judul penelitian Analisis Penerapan PSAK 18 untuk Dana Pensiun pada Yayasan Pendidikan Sekolah Bruder ingin mengetahui prosedur dan perlakuan akuntansi dana pensiun yang diterapkan pada Dana Pensiun Yayasan Pendidikan Sekolah Bruder apakah telah sesuai dengan Pedoman Standar Akuntansi Keuangan dengan yang diterapkan perusahaan serta membandingkan prosedur dan perlakuan akuntansi dana pensiun yang diterapkan oleh Dana Pensiun Yayasan Pendidikan Sekolah Bruder dan PSAK 18. Hasil penelitian menunjukkan bahwa proses akuntansi yang diterapkan oleh Dana Pensiun Yayasan Pendidikan Sekolah Bruder telah sesuai dengan PSAK 18 yang berlaku yaitu dilihat dari besarnya manfaat pensiun yang dijanjikan peserta yang dinilai berdasarkan masa kerja karyawan, faktor penghargaan masa kerja, dan penghasilan dasar pensiun.

Puspita dkk (2016) dengan judul penelitian Evalusi Penerapan Standar Akuntansi Keuangan Nomor 18 tentang Akuntansi dan Pelaporan Program Manfaat Purnakarya pada PT. Bank Negara Indonesia (Persero), Tbk., ingin menganalisis kesesuaian penerapan Standar Akuntansi Keuangan No.18 pada Pelaporan Dana Pensiun Bank Negara Indonesia. Hasil penelitian menunjukkan proses akuntansi yang diterapkan oleh Dana Pensiun Lembaga Keuangan BNI secara keseluruhan telah sesuai dengan PSAK No. 18.

Nussy (2014) dengan judul penelitian Analisis Penerapan PSAK No. 18 mengenai Akuntansi Dana Pensiun pada PT. Taspen Cabang Menado ingin menganalisis mengenai kesesuaian penerapan akuntansi dana pensiun pada Dana Pensiun Taspen Cabang Manado dengan Pernyataan Standar Akuntansi Keuangan (PSAK) No. 18. Hasil penelitian ini didasarkan pada Laporan Aktiva Bersih, Laporan Perubahan Aktiva Bersih, dan Neraca tahun 2012 dan 2013, menunjukkan hasil bahwa proses akuntansi yang diterapkan oleh Dana Pensiun Taspen secara keseluruhan telah sesuai dengan PSAK No. 18 tapi dalam pembayaran manfaat pasti (pendanaan program pensiun) yang akan dilakukan PT. Taspen Cabang Manado kepada karyawan yang masih bekerja dan yang sudah pensiun berdasarkan jasa yang telah diberikan, mengalami kekurangan dalam hal pengembangan dana investasi yang mengakibatkan kualitas pendanaan berada di tingkat ketiga (kekayaan dana pensiun lebih kecil dibanding kewajiban solvabilitas). Pimpinan perusahaan sebaiknya meningkatkan kekayaan dana pensiun dengan menaikkan pengembangan dana investasi dan meningkatkan kualitas pendanaan.

\section{Metodologi Penelitian}

\section{Jenis Penelitian}

Penelitian ini menggunakan metode deskriptif kualitatif, yaitu penelitian yang bertujuan untuk memahami fenomena atau gejala sosial dengan lebih menitikberatkan pada gambaran yang lengkap tentang fenomena yang dikaji dengan menempatkan teori pada data yang diperoleh (Bungin, 2007).

\section{Teknik Pengumpulan Data}

Teknik pengumpulan data yang dilakukan dalam penelitian ini sebagai berikut :

\section{Teknik Dokumentasi}

Pengumpulan data dan informasi yang dilakukan melalui buku, jurnal, maupun internet untuk mempelajari berbagai teori yang mendukung penelitian ini.

\section{Teknik Wawancara}

Pengumpulan data dilakukan dengan teknik wawancara atau pertukaran informasi dari dua pihak untuk mempertemukan 
berbagai macam ide atau masukan melalui tanya jawab.

\section{Hasil Penelitian}

\section{Gambaran Umum Dana Pensiun Universitas Surabaya}

Universitas Surabaya merupakan lembaga pendidikan tinggi yang menyelenggarakan jasa di bidang layanan pendidikan. Sebagai sebuah lembaga pendidikan, Universitas Surabaya juga berupaya meningkatkan kesejahteraan karyawannya. Untuk itu, Universitas Surabaya berdasarkan Peraturan Yayasan No. 07./SK/YUS/198 Bab IV menyatakan bahwa karyawan tetap yang diberhentikan dengan hormat atau telah mengabdi dalam kurun waktu tertentu wajib diberi uang pesangon. Dengan melihat kondisi keuangan Universitas Surabaya yang semakin membaik, Universitas Surabaya mengalihkan program tersebut menjadi Program Pensiun. Berdasarkan Keputusan Yayasan Universitas Surabaya, No. 052/SK/ YUS/IX/1996, Dana Pensiun Universitas Surabaya dibentuk secara resmi.

\section{Visi Dana Pensiun Universitas Surabaya}

Visi Dana Pensiun Universitas Surabaya adalah menjadi dana pensiun yang sehat dan mampu menunjang kepentingan pendiri dalam memberikan jaminan terpeliharanya kesinambungan penghasilan hari tua bagi para peserta.

\section{Misi Dana Pensiun Universitas Surabaya}

Misi Dana Pensiun Universitas Surabaya sebagai berikut:
1. Menyelenggarakan sistem kepesertaan program pensiun secara rapi, tertib, dan akurat;

2. Menyelenggarakan sistem penerimaan dan administrasi iuran pensiun secara tertib dan bertanggung jawab;

3. Menyelenggarakan pembayaran manfaat pensiun secara tertib dan tepat waktu;

4. Mengelola kekayaan investasi sesuai dengan arahan investasi pendiri dan ketentuan perundangan yang berlaku, aman, serta memberikan hasil investasi yang maksimal.

\section{Tujuan Dana Pensiun Universitas Surabaya}

Tujuan Dana Pensiun Universitas Surabaya adalah menyelenggarakan program pensiun manfaat pasti dengan tujuan memelihara kesinambungan penghasilan pada hari tua, sehingga akan menimbulkan ketentraman kerja dan meningkatkan motivasi kerja karyawan, yang merupakan iklim yang kondusif bagi peningkatan produktivitas lembaga Universitas Surabaya.

\section{Sumberdaya Universitas Surabaya}

Peserta Dana Pensiun Universitas Surabaya (Ubaya) sampai dengan awal tahun 2015 total sebanyak 667 orang peserta yang terdiri atas 653 orang peserta aktif dan 14 peserta tidak aktif. Pada akhir tahun menjadi 660 orang terdiri dari 642 orang peseerta aktif dan 18 orang peserta tidak aktif. Berikut tabel peserta sampai dengan akhir tahun 2015 (lihat Tabel 1).

Tabel 1. Jumlah Peserta Dana Pensiun Ubaya

\begin{tabular}{|l|c|c|c|c|c|}
\hline \multirow{2}{*}{ Uraian } & \multicolumn{2}{|c|}{ Tenaga Kependidikan } & \multicolumn{2}{c|}{ Tenaga Administrasi } & \multirow{2}{*}{$\begin{array}{c}\text { Total } \\
\text { Peserta }\end{array}$} \\
\cline { 2 - 5 } & Aktif & Pasca/cuti & Aktif & Pasca/cuti & 667 \\
\hline Peserta Awal & 287 & 11 & 266 & 3 & $(7)$ \\
\hline Perubahan Peserta & $(4)$ & 3 & $(7)$ & 1 & 660 \\
\hline Peserta Akhir & 283 & 14 & 359 & 4 & 6 \\
\hline
\end{tabular}




\section{Dasar Akuntansi dalam Penyusunan Laporan Keuangan Dana Pensiun Ubaya}

Kerangka dasar menurut Pernyataan Standar Akuntansi Keuangan adalah menyajikan konsep yang mendasari penyusunan dan penyajian laporan keuangan bagi penggunanya. Dasar akuntansi dalam menyusun laporan keuangan Dana Pensiun Universitas Surabaya berdasarkan pada SK Menteri Keuangan No. 509/KMK.06/2002 tanggal 4 Desember 2002 tentang Laporan Keuangan Dana Pensiun dan Pernyataan Standar Akuntansi Keuangan No. 18 tentang Akuntansi Dana Pensiun yang diterbikan oleh Ikatan Akuntan Indonesia. Sedangkan penilaian investasi mengacu kepada Peraturan Ketua Badan Pengawas Pasar Modal dan Lembaga Keuangan No. PER-05/
BL/2012 mengenai Penyusunan Laporan Keuangan dan Dasar Penilaian Investasi bagi Dana Pensiun. Laporan keuangan yang disusun Dana Pensiun Universitas Surabaya telah sesuai dengan peraturan. Laporan yang disusun mulai dari tahun 2013, 2014, dan 2015 terdiri atas:

1. Laporan Aset Neto;

2. Laporan Perubahan Aset Neto;

3. Laporan Neraca;

4. Catatan atas Laporan Keuangan;

5. Perhitungan Hasil Usaha;

6. Laporan Arus Kas.

Laporan keuangan tersebut disusun secara tahunan, dan disajikann dalam mata uang rupiah, serta dinyatakan dengan dasar

Tabel 2. Perbandingan Penyajian Laporan Keuangan Dana Pensiun Universitas Surabaya dengan Pernyataan Standar Akuntansi Keuangan No. 18

\begin{tabular}{|c|c|c|c|}
\hline \multirow[t]{2}{*}{ Pengungkapan Laporan Keuangan PSAK no. 18} & \multicolumn{3}{|c|}{$\begin{array}{c}\text { Kesesuaian Laporan Keuangan } \\
\text { Dana Pensiun Universitas } \\
\text { Ssurabaya. } \\
\end{array}$} \\
\hline & 2015 & 2014 & 2013 \\
\hline \multicolumn{4}{|l|}{ Laporan Aset Neto } \\
\hline a. Aset pada akhir periode bersangkutan & Sesuai & Sesuai & Sesuai \\
\hline b. Dasar penilai asset & Sesuai & Sesuai & Sesuai \\
\hline $\begin{array}{l}\text { c. Rincian setiap investasi tunggal tersedia } \\
\text { manfaat purnakarya atau } 5 \% \text { untuk setiap } \\
\text { kelas atau jenis surat berharga }\end{array}$ & Sesuai & Sesuai & Sesuai \\
\hline d. Rincian setiap investasi pemberi kerja & Sesuai & Sesuai & Sesuai \\
\hline \multirow[t]{2}{*}{$\begin{array}{l}\text { e. Liabilitias kecuali nilia kini aktuaria atas } \\
\text { manfaat purnakarya terjanji }\end{array}$} & Sesuai & Sesuai & Sesuai \\
\hline & Sesuai & Sesuai & Sesuai \\
\hline Laporan Perubahan Aset Neto & Sesuai & Sesuai & Sesuai \\
\hline a. Iuran pemberi kerja & Sesuai & Sesuai & Sesuai \\
\hline b. Iuran karyawan & Sesuai & Sesuai & Sesuai \\
\hline $\begin{array}{lllll}\text { c. } & \begin{array}{l}\text { Pendapatan investasi seperti } \\
\text { deviden }\end{array} & \text { bunga dan } \\
\end{array}$ & Sesuai & Sesuai & Sesuai \\
\hline d. Pendapatan lain lain & Sesuai & Sesuai & Sesuai \\
\hline e. Manfaat yang dibayarkan dan terutang & Sesuai & Sesuai & Sesuai \\
\hline f. $\quad$ Beban Administrasi & Sesuai & Sesuai & Sesuai \\
\hline g. Beban lain lain & Sesuai & Sesuai & Sesuai \\
\hline $\begin{array}{l}\text { h. Laba rugi pelepasan investai dan perubahan } \\
\text { nilai investasi }\end{array}$ & Sesuai & Sesuai & Sesuai \\
\hline $\begin{array}{ll}\text { i. } & \text { Transfer dari dan untuk program dana pensiun } \\
\text { lain }\end{array}$ & sesuai & sesuai & sesuai \\
\hline
\end{tabular}


harga perolehan dan dasar akrual, kecuali untuk investasi tertentu yang mengacu pada nilai wajar. Laporan arus kas disusun menggunakan metode langsung dengan mengklasifikasi arus kas ke dalam tiga aktivitas, yaitu:

1. Arus kas bersih dari aktivitas investasi;

2. Arus kas dari aktivitas operasional;

3. Asus kas dari aktivitas pendanaan.

Nilai kas pada akhir periode tahun 2015, 2014, dan 2013 juga telah menunjukkan nilai yang sama dengan nilai "Kas dan Bank " asset lancar di luar investasi pada laporan asset neto dan laporan neraca.

\section{Laporan Aset Neto}

Sesuai dengan Peraturan Ketua Badan Pengawasan Pasar Modal, No: PER 05/ BL/2012, menjelaskan bahwa laporan asset neto merupakan laporan aktiva bersih. Dalam PSAK No. 18 dinyatakan bahwa Laporan Aset Neto adalah laporan yang berisi mengenai aset bersih pada akhir periode. Laporan Aset Neto Dana Pensiun Universitas Surabaya tahun 2015, 2014, dan 2013 telah disusun sesuai dengan Peraturan Ketua Badan Pengawasan Pasar Modal dan telah seuai dengan PSAK No. 18. Dalam penyusun laporan asset neto Dana Pensiun Universitas Surabaya merinci perkiraan dengan klasifikasi sebagai berikut:

1. Aset:

a. Investasi:

- Investasi;

- Surat Berharga;

- Tabungan;

- Deposito;

- Saham;

- Obligasi;

- Sukuk;

- Unit Penyertaan Reksadana;

- Tanah;

- Penembatan Langsung;

- Tanah dan Bangunan.

b. Aset Lancar di Luar Investasi:

- Kas dan Bank;

- Piutang Iuran;

- Piutang invesatasi;

- Piutang hasil investasi;

c. Aset Operasional:

- Peralatan computer;

- Peralaatan Kantor;

- Aset Operasi Lain.

2. Liabilitas:

- Liabilitas di luar nilai kini aktuaria;

- Utang manfaat pensiun jatuh tempo;

- Utang investasi;

Tabel 3. Perubahan Peserta Dana Pensiun Universitas Surabaya

\begin{tabular}{|l|c|c|}
\hline \multirow{2}{*}{ Keterangan } & \multicolumn{2}{|c|}{ Perubahaan Peserta } \\
\cline { 2 - 3 } Peserta Awal & $\mathbf{2 0 1 5}$ & $\mathbf{2 0 1 4}$ \\
\hline Penambahan : & $\mathbf{6 6 7}$ & $\mathbf{6 5 4}$ \\
\hline - Peserta baru & 12 & 32 \\
\hline - Peserta dari program dana pensiun lain & 0 & \\
\hline Pengurangan : & & \\
\hline - Peserta pensiun Normal & 9 & 10 \\
\hline - Peserta pensiun karena meninggal dunia & 2 & 2 \\
\hline - Peserta Pensiun ditunda & 6 & 3 \\
\hline - Peserta yang keluar dengan hakatas pengembalian iuran peserta & 0 & 4 \\
\hline dan pengembangan & & 0 \\
\hline Pensiun dipercepat & 2 & 6 \\
\hline Total & 660 & 6 \\
\hline
\end{tabular}


- Utang pemberi kerja;

- Pendapatan diterima di muka;

- Beban masih harus dibayar;

- Liabilitas lain-lain.

\section{Laporan Perubahan Aset Neto}

Dalam menyajikan laporan perubahan asset neto, dana pensiun juga harus menyesuaikan dengan Peraturan Ketua Badan Pengawasan Pasar Modal dan juga PSAK No. 18. Laporan Perubahan Aset Neto tersebut berisikan mengenai informasi tentang perubahan atas jumlah asset neto yang tersedia untuk manfaat pensiun serta menguraikan penyebab terjadinya perubahan dana pensiun dalam suatu periode tertentu. Dalam menyusun perubahan asset neto tersebut harus diuraikan terjadinya perubahan sebagai berikut:

1. Penyebab penambahan dana pensiun;

2. Penyebab pengurangan dana pensiun.

Perubahan asset neto Dana Pensiun Universitas Surabaya dapat dilihat berdasarkan laporan perubahan asset neto yang telah disusun. Berikut adalah laporan perubahan asset neto yang telah disusun, dengan menguraikan pos-pos perkiraan sebagai berikut:

1. Penambahan
a. Pendapataan investasi;
b. Bunga/Bagi hasil;
c. Dividen;
d. Sewa;
e. Laba (Rugi) pelepasan investasi;
f. Pendapatan investasi lain;
g. Peningkatan (penurunan) investasi;
h. Iuran Jatuh Tempo;
i. Iuran Normal pemberi kerja;
j. Iuran Normal peserta;
k. Pendapatan di luar investasi.

2. Pengurangan
a. Beban Investasi;
b. Beban operasional;
c. Beban di luar investasi dan operasional;
d. Manfaat pensiun;
e. Pajak Penghasilan;

f. Pengalihan dana ke dana pensiun lain.

3. Kenaikan (Penurunan) Aset Neto

4. Aset neto awal tahun

5. Aset neto akhir tahun.

\section{Laporan Neraca}

Laporan Neraca dana pensiun merupakan gambaran mengenai kekayaan dan kewajiban dana pensiun, baik kewajiban manfaat pensiun maupun kewajiban lainnya. Informasi pada neraca Dana Pensiun Universitas Surabaya telah sesuai dengan PSAK 18 dan disusun berdasarkan nilai historis.

Selisih nilai kini aktuaria merupakan selisih perbedaan dasar penilaian antara harga perolehan atau nilai buku dengan nilai wajar atas investasi dana pensiun. Liabilitas terdiri atas nilai kini aktuaria yang merupakan kewajiban manfaat pensiun pada karyawan dan liabilitas di luar nilai kini aktuaria. Sedangkan perhitungan nilai kini aktuaria ditentukan melalui aktuari yang ditunjuk. Berikut adalah pos-pos Laporan Neraca Dana Pensiun Universitas Surabaya:

1. Aset
a. Investasi;
b. Selisih Penilaian Investasi;
c. Aset Lancar di luar Investasi;
d. Aset Operasional;
e. Aset lain-lain.

2. Liabilitas
a. Nilai Kini Aktuaria;
b. Selisih Nilai Kini Aktuaria;
c. Liabilitas di luar Nilai Kini Aktuaria.

\section{Aktuaria}

Nilai kini aktuaria berupa nilai sekarang pembayaran manfaat pensiun yang akan dilakukan dana pensiun kepada karyawan yang masih bekerja dan yang sudah pensiun yang dihitung berdasarkan jasa yang telah diberikan, masing-masing dirinci sebagai berikut:

$\begin{array}{ll}\text { Saldo awal } & \text { Rp 57.845.330.000 } \\ \text { Penyesuaian nilai kini aktuaria } & \text { Rp 15.090.988.544 } \\ \text { Nilai kini aktuaria } & \text { Rp 72.936.318.544 }\end{array}$ 
Nilai kini aktuaria sebesar $\mathrm{Rp}$ 72.936.318.544 merupakan hasil proyeksi valuasi konsultan aktuaria, sedangkan penyesuaian nilai kini aktuaria sebesar Rp 15.090.988.544, merupakan selisih antara nilai kini aktuaria 2015 dan 2014 dengan saldo nilai kini aktuaria periode sebelumnya.

Dana Pensiun Universitas Surabaya tidak menerima transfer dari dan untuk program dana pensiun dari lembaga dana pensiun lain. Perubahan kepesertaaan dana pensiun dikarenakan adanya penambahan peserta baru (karyawan baru) dan peserta keluar karena adanya pensiun normal, pensiun meninggal, pensiun ditunda, ada peserta yang keluar dengan hak atas pengembalian iuran peserta dan pengembangannya. Berikut perubahan peserta dana pensiun Universitas Surabaya (lihat Tabel 3).

\section{Kebijakan Pendanaan}

Arah dan kebijakan investasi Dana Pensiun Universitas Surabaya merujuk pada Keputusan Yayasan Universitas Surabaya No.12/SK/YUS/III/2008 tanggal 3 Maret 2008 dan No.107/SK/YUS/XI/ 2011 tanggal 28 Nopember 2011 tentang Arahan Investasi Dana Pensiun Universitas Surabaya. Arahan dan kebijakan investasi tersebut dimaksudkan agar pengurus dalam menjalankan pengelolaan dana pension tetap berdasarkan pada Undang Undang Dana Pensiun yang berlaku sekaligus mencapai hasil investasi yang optimal. Arahan dan kebijakan investasi meliputi target investasi dan diversifikasi kekayaan dana pensiun ke dalam jenis investasi yang ideal sehingga diharapkan portofolio yang dipilih adalah yang paling aman sekaligus menguntungkan untuk pengembangan kekayaan dana pensiun.

Kualitas pendanaan Dana Pensiun Universitas Surabaya pada tahun 2015 masuk dalam kategori KUALITAS PENDANAAN
SATU (kategori 1). Asset neto tahun 2015 mengalami peningkatan sebesar Rp 73.801.429.874 dengan kewajiban aktuaria sebesar Rp 72.936.318.544 sehingga mengalami surplus sebesar Rp 86.511.330, meningkat dibanding tahun 2014. Berdasarkan capaian tersebut dewan pengawas menilai bahwa investasi dan posisi dana yang dikelola oleh pengurus Dana Pensiun Universitas Surabaaya dalam kondisi bagus.

\section{Simpulan}

Kesimpulan yang dapat diambil dari penelitian ini adalah:

1. Laporan Keuangan Dana Pensiun Universitas Surabaya pada tahun 2013-2015 telah sesuai dengan Pernyataan Standar Akuntansi Keuangan (PSAK) 18. Hal tersebut menandakan bahwa Pengelola Dana Pensiun Universitas Surabaya telah mematuhi peraturan perundangundangan yang berlaku baik Undang Undang Nomor 11 Tahun 1992 dan PSAK No. 18 sebagai acuan dalam menyusun laporan keuangan.

2. Sumber pendanaan berasal dari iuran peserta Dana Pensiun Universitas Surabaya.

3. Dana Pensiun Universitas Surabaya menggunakan bantuan aktuaris dalam mengestimasi manfaat purnakarya yang akan diterima peserta.

4. Kualitas pendanaan Dana Pensiun Universitas Surabaya tahun 2015 telah masuk dalam kategori pendanaan satu. 


\section{Daftar Pustaka}

Bungin, Burhan. 2007. “Format dan Model Kualitatif”. Dalam Burhan Bungin (ed.). Metodologi Penelitian Kualitatif. Jakarta: PT Raja Grafindo Persada.

Nussy, Andika. 2014. “Analisis Penerapan PSAK No. 18 Mengenai Akuntansi Dana Pensiun pada PT. Taspen Cabang Manado". Jurnal EMBA, Vol 2, No. 4.

Puspitasari, dkk. 2016. Evaluasi Penerapan Standar Akuntansi Keuangan Nomor 18 tentang Akuntansi dan Pelaporan Program Manfaat Purnakarya Pada PT Bank Negara Indonesia (Persero), Tbk. Jurnal EMBA, Vol.4, No.1 Maret 2016, Hal. 231-241.

Saefuloh, dkk. 2015. Kebijakan Pengelolaan Dana Pensiun Sektor Corporation. Jurnal Ekonomi \& Kebijakan Publik, Vol.6 No.1, Juni 2015. Hal. 77-96.

Taswan. 2015. Akuntansi Perbankan. Edisi III. Yogyakarta: UPP STIM YPKN.

Thomas. 2017. "Analisis Penerapan PSAK 18 Untuk Dana Pensiun Pada Yayasan Pendidikan Sekolah Bruder". Jurnal Kajian Ilmiah Akuntansi Fakultas Ekonomi UNTAN (KIAFE), Vol 6, No 2.

Wahab, Zulaini. 2005. Dana Pensiun dan Jaminan Sosial Tenaga Kerja di Indonesia. Bandung: Citra Aditya Bakti.

Buletin Dana Pensiun Ubaya Tahun 2013, 2014, dan 2015.

Pemerintah Republik Indonesia. Keputusan Menteri Keuangan Nomor 509/KMK.06.2002 tentang Laporan Keuangan Dana Pensiun. Jakarta.

Pemerintah Republik Indonesia. 1992. Undang Undang No. 11 Tahun 1992 tentang Dana Pensiun. Jakarta.

Standar Akuntansi Keuangan. 2004. Standar Akuntansi Keuangan. Jakarta: Salemba Empat. 